\title{
MIDAS
}

Museus e estudos interdisciplinares

$4 \mid 2014$

Varia e dossier temático: "Museus, utopia e urbanidade"

\section{Imaginary museums: What mainstream museums can learn from them?}

Museus imaginários: 0 que podem os museus mainstream aprender com eles?

\section{Rachel Morris}

\section{(2) OpenEdition}

\section{Journals}

Electronic version

URL: http://journals.openedition.org/midas/643

DOI: $10.4000 /$ midas.643

ISSN: 2182-9543

Publisher:

Alice Semedo, Paulo Simões Rodrigues, Pedro Casaleiro, Raquel Henriques da Silva, Ana Carvalho

Electronic reference

Rachel Morris, «Imaginary museums: What mainstream museums can learn from them? », MIDAS

[Online], 4 | 2014, Online since 13 February 2015, connection on 20 April 2019. URL : http://

journals.openedition.org/midas/643; DOI : 10.4000/midas.643

This text was automatically generated on 20 April 2019.

\section{cc) (†)}

Midas is licensed under a Creative Commons Attribution-NonCommercial-ShareAlike 3.0 International License 


\title{
Imaginary museums: What mainstream museums can learn from them ${ }^{1}$
}

Museus imaginários: O que podem os museus mainstream aprender com eles?

\author{
Rachel Morris
}

1 The history of imaginary museums is a long and curious one. It also has more relevance for real-world museums than might at first sight be apparent.

2 The world, when one stops to think about it, abounds in imaginary museums. There are museums on paper, created by writers and artists; there are virtual museums on the web; there are museum catalogues that amount to museums in themselves; there are conceptual museums, conceived of and designed in every detail before they are built; and there is even the version of a museum that we all carry in our heads when we step into a real one - because just as no two readers ever read the same book so no two visitors ever go into the same museum.

3 More subtly, there are museums that are real enough - and yet have a distinct thread of imagination running through them. Not surprisingly these are usually the creation of one inspired individual. Take Sir John Soane's Museum in Lincolns Inn Fields where downstairs in the Monks Yard Soane created the sham ruins of a monastery, with broken arches, pediments and other architectural fragments. Ruins of course were a fashion of the times, but from what we know about Soane's character we can also see that he was storytelling using things and three dimensions, and what's more, telling a very particular story, a story about himself. The Soane Museum is a form of autobiography (Woodward 2002) - for ruins, it seems, expressed Soane's feelings of unhappy persecution. Confirmation of his taste for storytelling comes from a short story that he wrote called 'Crude Hints towards a History of my house', in which he imagined visitors coming to his house at some future time when Lincolns Inn Fields lie in ruins and visitors are trying to make sense of them. Soane was a storyteller by instinct - and was creating a museum, as 
many artists and writers have done since, as a way to tell stories about the world and about himself.

4 Snowshill Manor in Gloucestershire is another inspired creation by an artist trying to understand himself through things - this time the architect Charles Wade who spent his life collecting and displaying the abandoned mementoes of other ages with such talent that the objects seem to quiver on the verge of life. They include, bafflingly, two dozen Samurai Warriors, some of them mysteriously picked up by Wade in a local junk shop in Cheltenham. As at the Soane Museum, a thread of gifted imagination and playfulness runs through Snowshill, as well as sadness at the passing of time and, in Wade's case, a yearning for childhood - his favourite room in the house was an attic room called 'Seventh Heaven' which he filled with toys from his childhood. These threads of feeling playfulness but also sadness, a yearning for lost times, the sensation of there being a lost paradise at the beginning of our lives - are all themes that occur again and again in imaginary museums.

So there are many kinds of imaginary museums but the two that interest me here are those imaginary museums created by people who would think of themselves as novelists, artists or film makers - and those that have one foot in more conventional museummaking, that are often indeed described as museums, but still have a powerful thread of imagination running through them.

Imaginary museums turn up all kinds of interesting questions. They make us wonder why writers and artists use the museum as a metaphor and what it enables them to say? What kinds of imaginary museums do they create? Why some people story-tell with things? Do all museums have a thread of fiction-making and imagination running through them? And what happens when these imaginary museums overturn the basic principle of real museums - that they should tell historical truths? And the more I have looked at these questions the more it has seems to me that this subject isn't a whimsical divergence from the study of mainstream museums, but that - as the title of this paper suggests - there is much that real museums can learn from paper ones.

The first thing to be said is that museums and novels share a lot in common. Each affords us the pleasures that come from entering complete and self-contained worlds, and what's more, worlds that have been reduced to a miniature scale, at least in comparison with the universe that they reflect. Even the biggest museum in the world is smaller than the universe it describes - or, to put it another way, all museums are games of boxes inside boxes. Likewise a novel is a world between book covers and small enough to carry in one's hand. Human beings love to enter miniature worlds and the secret pleasures of both novels and museums is that they allow us to do exactly this. ${ }^{2}$

8 The second thing to be said is that inventing paper museums is nothing new. The seventeenth-century English philosopher Thomas Browne described in words a museum that he called the Musaeum Clausum, the 'Closed or Secret Museum'. Some of the fantastical, imaginary objects in his museum included 'A large Ostrich's Egg, whereon is neatly and fully wrought that famous battle of Alcazar, in which three Kings lost their lives' and 'A Glass of Spirits made of Ethereal Salt, Hermetically sealed up, kept continually in Quick Silver and so volatile a nature that it will scarcely endure the Light'.

9 Now it's clear from reading his book that the Musaeum Clausum was a deliberate, knowing invention of Browne's and what's more, one with a strong thread of playful pleasure running through it. It's the same thread of playful pleasure that one also sees at 
the Museum of Jurassic Technology in California - which, as everyone knows, is an apparently truthful but actually largely invented Cabinet of Curiosities in Los Angeles, featuring a cast of mostly imaginary characters - although, to the deep and delightful confusion of the visitors, not all of them are invented. Again there is the playfulness of imaginary museums - although the other interesting aspect of the Museum of Jurassic Technology is that it is a deeply old-fashioned display, as well as a deeply beautiful one. David Wilson, the museum's creator, builds all his effects around objects in showcases which has been the language and grammar of museums for hundreds of years. Showcases, it seems, still have considerable potential for story-telling. But the most curious thing about the Museum of Jurassic Technology is that although its lack of historical truth shifts its appeal into a different area, it does not diminish it at all.

There's another interesting aspect to Browne's paper museum and that is that in the seventeenth century, as Paula Findlen (2004) has shown us, books that described museums, whether real or imaginary, were themselves called 'museums' and were thought to be museums just as much as real one. It is easy to see why. There are obvious parallels between knowledge contained within the straight lines of the page and knowledge contained within the straight lines of the showcase or the room.

But invented museums go back even further than Thomas Browne and the seventeenth century. If you remember Homer's Iliad you will remember the long, beautiful but slightly baffling passage in Book 18 in which the god Hephaistos creates a magical shield for the hero Achilles. On this Shield the god Hephaistos depicts the earth, the sea and the heavens, and the sun, the moon and all the stars. He also depicts two cities, the one full of dancing, singing and marriage feasts, and the other afflicted by war, battles and the siege of a great city - in other words, a miniature version of the War outside the Walls of Troy. $\mathrm{He}$ also depicts fields being ploughed and harvested, vineyards teeming with grapes, a young boy singing, a lion hunt and young men dancing and courting women. In short, he creates an entire miniature universe on Achilles' Shield and around it depicts the River of Ocean, as if to fence it in.

Now what Homer is describing is not a museum - in the sense of a building with objects in it - but it does nonetheless have a distinctly museum-y quality about it, the reason being that the description of the Shield shares with museums the feeling of being a miniature world, an entire universe shrunk down and recreated in microcosm. What's more, by putting into this poem, which describes the siege of a city, a miniature depiction of a city under siege, he has heightened 'the Russian doll' feeling of miniature worlds within miniature worlds, each getting progressively smaller - a game that seems to have a universal appeal.

If we now look at more recent novels it seems that there are four qualities of museums and objects that novelists tune into.

The first is to do with the power of objects to help us remember the past. The Turkish Nobel-prize winning novelist Orhan Pamuk has published a novel called 'The Museum of Innocence' about a man called Kemal who loves a woman so obsessively that he creates a museum to this love affair, filling it with the everyday items that chart the mostly tragic course that his love takes. It's a good novel and it has a lot of interesting things to say about museums and the different ways in which human beings use objects, reaching through the form of fiction some of the same conclusions that academics such as Susan Pearce (1995) have reach through scholarship. In particular it talks about objects as carriers of memories and mechanisms to take us back to happier days and to release us 
from the terrible, forward-flow of time, although, as the story goes on, Kemal's feelings for things also becomes fetishistic - in other words, he uses objects to soothe and comfort himself whilst also releasing his secret desires. Pamuk, who is apparently a great museum-goer, knows that one of the great strengths of museums is that they can help visitors go back in time. For Pamuk a museum is a metaphor for the mind as a treasure store of memories and as somewhere where 'time becomes a place' not only for individuals but for cities, cultures and peoples.

the autumn of 2009 Pamuk gave the Norton lectures at Harvard and in the course of these he made it clear that he believes that the history of novels and the history of museums are linked through the industrial revolution of the nineteenth century which flooded the world with things, giving novels, such as Dickens', a new found physicality as well as spurring on the development of Victorian museums.

Now, in a nice twist of his imagination Pamuk has also created a real version of his imaginary museum in a house in Istanbul. From interviews that he is given we can see that for Pamuk, making museums is an exercise in autobiography, like writing or filmmaking. Pamuk says, 'In building my own museum I don't want to exhibit power but to express my interiority, my spirit. A museum should express the spirituality of the collector' (Pamuk 2010). It's an interesting ambition because it says that museums can do what novels do, that both are the means by which we can explore our inner worlds and express their unique flavour and texture, although the one uses words and the other things.

The second quality about museums that writers love is the apparent 'alive-ness' of objects. In the film 'Night at the Museum' (released 2006) the plot is built around the idea that the things in the museum - stuffed lions, miniature soldiers, toy cowboys - come alive at night. It's an idea that works for children in particular - it's how they play with dolls and toys - but it relates closely to the willingness of all human beings of any age to invest objects with innate power. In Wilkie Collins' nineteenth-century novel, 'The Moonstone', the Moonstone is a sacred treasure, holy to the Hindu faith, and watched and guarded by generations of priests, but also cursed for anyone who steals it - which of course they do. First, the Muslim emperor, Aurungzebe, steals it and then, after many adventures it arrives at last into the possession of Tipu Sultan, and from him - through the sack of his kingdom, Seringapatam - into the hands of British soldiers and from there to a beautiful and innocent heiress from Yorkshire called Rachel Verinder. The story of the Moonstone deliberately stirs up memories of the Koh-i-Noor, another Victorian jewel with a mythical aura but this time entirely real, also with a curse hanging over it and thus with a worrisome power.

My point here is not that objects have mythical powers but that novelists and film makers understand the tendency of their audiences to see them in this way.

But museums are not only about individual objects; they are also about collections of things. Groups of things are interestingly different from individual objects - they have a different power over us - and the power of strange collections is the third quality about museums that novelists fasten onto. Angela Carter's classic novel from the 1980's, 'Nights at the Circus', begins with her heroine Fevvers incarcerated inside a late Victorian Museum of Monsters before she joins the strange inhabitants of a circus at the beginning of the twentieth century (Carter 1984). Fairs and circuses of course are historically first cousins to museums (through the evolution of the cabinets of curiosities) and share much in common with museums. In particular, what they share in common is the fact that both 
are collections of strange, valuable or unusual things, animals or people, who are put on show for the entertainment, education or enlightenment of others. For Carter museums are as much about stories (tall stories, if you like) as they are about things or people. Her novel is a nest of stories inside stories, and the tensions she is exploiting are the same tensions you sometimes feel inside museums, between the power of the strange objects inside the showcases and the straight, confining, formal lines of the showcases themselves.

Angela Carter's novels are in the same tradition as medieval writings on wonders and marvels - for instance, Marco Polo's descriptions of his fantastical journeys. Each of Marco Polo's cities is a wondrous object collected and confined within the pages of his book - so in a way his book too is a paper museum. ${ }^{3}$ Now in the twentieth century Italo Calvino rewrote Marco Polo's travels in a book called 'Invisible Cities - and Italo Calvino is strongly connected to Angela Carter through a style of writing called magical realism that both of them shared. It is noticeable how often it is writers with a taste for magical realism that respond to museums or to objects in museums. In other words, novelists respond to some streak of the irrational or the magical that they detect in museums - and which museums themselves mostly do not notice.

There is a fourth quality about museums that writers tune into, which we see in the short stories of the Argentinian writer Jorge Luis Borges, born in the late nineteenth century, and who - after he went blind - became chief librarian in the national library in Buenos Aires. It is a strange and fantastical life story (although entirely true) and Borges' stories are similarly erudite, surreal and strangely fantastical. In one of his essays (Borges 2001) he writes that in a certain Chinese encyclopedia entitled, 'The Celestial Emporium of Benevolent Knowledge' it is said that 'animals are divided into (a) those that belong to the Emperor, (b) embalmed ones, (c) those that are trained, (d) suckling pigs, (e) mermaids, (f) fabulous ones, (g) stray dogs, (h) those that are included in this classification, (i) those that tremble as if they were mad, $(\mathrm{j})$ innumerable ones, $(\mathrm{k})$ those drawn with a very fine camel's hair brush, (l) others, (m) those that have just broken a flower vase, (n) those that resemble flies from a distance.

Now it is not at all clear that the 'Celestial Emporium of Benevolent Knowledge' ever existed. Many people have tried to track it down, but as far as I know no one has ever done so - and it is always the case with Borges that the more he buttresses his prose with footnotes and erudite references the more likely he is to be making the whole lot up. But this quote, whether true or not, has always caught people's imagination, and it has an obvious relevance for museums which are all about ways of categorising the world. What's interesting is that the ways in which museums choose to shape and categorise the world can have great poetic power and resonance over our imaginations - particularly when the mode of categorising is as unexpected as in this quote from Borges. Storytelling in museums resides at this level just as much as in the level of words on graphic panels.

In fact Borges' prose has in general a very museum-y feeling - all his writing, both fact and fiction, blends a very precise style (a taste for dates, titles and footnotes) with a pleasure in the fantastical - which, incidentally, is exactly the same quality we find at The Museum of Jurassic Technology.

But why should any of this matter to real museums in the real world? The reason, I think, is as follows and relates to the peculiar nature of museums. 

conceptual places with an innate pathos and poignancy that comes from the fact that their subject is Time and the different journeys that things and people make through time. They also bear strong similarities to zoos, botanical gardens, treasuries, bestiaries, libraries, collections of poetry and many more. So fluid is the concept of a museum that you would think that it would slip away through one's fingers - and yet it doesn't because it also has a strong, concrete existence. This double existence in both the physical and the imaginative world and their aura of poignancy means that the museums can be powerful and robust metaphors, through which writers can talk about loss, fear, yearnings for the past, and feelings of un-belonging.

and artists know all about the imaginative power of museums and play around accordingly with this power, stirring up all kinds of emotions in us, including playfulness, poignancy, reverence and fear for the power of objects. Interestingly enough visitors also understand the imaginative powers of museums. Morris Hargreave McIntyre, the research consultancy (Borges 2001), has explored the reasons why visitors come to museums - and has shown that their motivation can be broken down into four main reasons - educational, social, spiritual and emotional. Which of the four reasons is uppermost varies from visitor to visitor and museum to museum but all are almost always there, in one proportion or another. What is interesting though is that whilst most museums are happy to respond to the need to educate their visitors they are in general less comfortable satisfying the other three motivations. The desire for social, spiritual and emotional satisfaction that visitors bring to museums is closely connected to their desire to use their imaginations, but is very often ignored by museums. In other words visitors come to museums with their imaginations ready to be deployed, only to find that their imaginations are not required.

Morris Hargreave McIntyre have also mapped the steps by which visitors move through museums ready to use their empathy, creativity and understanding in order to reach a state of emotional and imaginative openness. It's a journey that requires museums also to play their parts, by offering back to the visitors atmosphere and opportunities to feel.

This brings us to another interesting observation, this time concerning the Dennis Severs house in Spitalfields in London. ${ }^{4}$ It is a dense and poetic reconstruction of an eighteenthcentury merchant's house created in the 1980's by a Californian artist called Dennis Severs. The house works in the same way that films and novels also work, by demanding of the visitors that they use their imaginations. Far from discounting the visitor's imagination Dennis Severs knew that he needed to work with it in order to create his effects - and says as much, in his directions to the visitors as they move around the house.

The enthusiasm of visitors to use their imaginations is something that we discovered when Metaphor created the exhibition of 'The First Emperor: China's Terracotta Warriors' at the British Museum in 2008, a show that we wanted to be both rigorously scholarly and deeply imaginative. We aimed to meet the visitors' imaginations half way, and did so by using the layout of the exhibition to turn the content into a story - and then by heightening the atmosphere of the story through lighting that responded to the tomblike architecture of the space. Audience evaluation showed that the exhibition was hugely successful, both in visitor numbers and in visitor satisfaction. 
writers and artists understand the imaginative power of museums. And so also do visitors who arrive ready to have their imaginations set on fire. It only remains for museums to satisfy these imaginations. And this, I think, is my point - that although writers, artists and visitors all understand the power that museums can have over our imaginations - not enough museums think that the visitors' imagination - or indeed their own - is relevant to the visitors' experience. It should be. It is.

\section{BIBLIOGRAPHY}

Borges, Jorge Luis. 2001. “John Wilkin's Analytical Language.” In The Total Library Non-Fiction 1922-1986, 229 - 232. London: Penguin Books.

Findlen, Paula. 2004. "The Museum: Its Classical Etymology and Renaissance Genealogy.” In Museum Studies: An Anthology of Contexts, edited by Bettina Carbonell, 30 - 32. Oxford: Blackwell Publishing.

Greenblatt, Stephen. 2004. "Resonance and Wonder." In Museum Studies: An Anthology of Contexts, edited by Bettina Carbonell, 541-555. $1^{\text {st }}$ ed. Oxford: Blackwell Publishing.

McIntyre, Morris Hargreave. 2009. The First Emperor: China's Terracotta Warriors (unpublished report 2008).

Pamuk, Orhan. 2010. “To Solve Turkey's Culture Clash, Old Elite Must Yield to Free Speech." Christian Science Monitor, Nov. 11, 2009. Accessed April 4, 2010. www.csmonitor.com/ Commentary/Opinion/2009/1111/p09s01-coop.html.

Pearce, Susan. 1995. On Collecting: an Investigation Into Collecting in the European Tradition. London: Routledge.

Woodward, Christopher. 2002. In Ruins. London: Vintage.

\section{NOTES}

1. This essay was first published in MacLeod, Suzanne, Laura Hourston Hanks, and Jonathan Hale, eds. 2012. Museum Making: Narratives, Architectures, Exhibitions. London and New York: Routledge. 2. John Mack on miniatureness.

3. Greenblatt $(2004,551)$ also points out that Marco Polo's writings are paper museums.

4. The Dennis Severs House, 18 Folgate Street, London E1 6BX. 


\section{ABSTRACTS}

The world is full of museums that don't exist fully in three dimensions - museums described in words or drawn on paper; museum catalogues; museums on the web. There are also many museums that are the creation of artists, novelists and poets, and so have a strong thread of imagination running through them. The latter cast an interesting light on 'real' museums and compel us to ask: What is it that the metaphor of a museum enables writers and artists to say? The question is doubly interesting because there is a long history of these 'imaginary' museums created by artists. This paper suggests that there are five qualities of museums that writers and artists tune into: the power of objects to take us back in time; the apparent 'alive-ness' of objects; the power of collections (which is different to the power of individual objects); the ability of museums to shape the world and tell us stories about it; and the role of museums as powerful metaphors through which we can talk about loss, fear and yearnings for the past. So writers and artists find museums powerfully imaginative places; but then so do visitors. Visitor research shows that visitors come to museums ready to use their imaginations. So my question is: Do 'real' museums do enough to work with the visitors' imaginations? Or, to put it another way, Do enough museums think that the visitors' imagination - and indeed their own - is relevant to the museum experience? It should be. It is.

O mundo está cheio de museus que não existem plenamente em três dimensões - museus descritos por palavras ou desenhados sobre papel; catálogos de museus; museus em rede. Há também muitos museus que são criação de artistas, romancistas e poetas e que, como tal, são percorridos por uma poderosa linha de imaginação. Estes lançam uma reveladora luz sobre os museus "reais" e levam-nos a perguntar: o que é que a metáfora do museu suscita a escritores e artistas? A questão é duplamente interessante, na medida em que é longa a história destes museus "imaginários" criados por artistas. O presente artigo sugere que há cinco características dos museus que os escritores e artistas tendem a focar: a capacidade dos objectos para nos fazer recuar no tempo; a aparente "vida" dos objectos; o poder das colecções (que é distinto do poder individual dos objectos); a capacidade dos museus para configurar o mundo e para nos contar histórias sobre ele; e o papel dos museus como potentes metáforas, através das quais é possível falar sobre os sentimentos de perda, medo e anseio em relação ao passado. Nesse sentido, escritores e artistas encaram os museus como lugares poderosamente imaginativos; e o mesmo acontece com os visitantes. Os estudos de público mostram que os visitantes chegam aos museus preparados para utilizar a sua imaginação. Sendo assim, a minha questão é: farão os museus "reais" o suficiente para mobilizar a imaginação dos visitantes? Ou, dito de outra forma: haverá museus suficientes a considerar que a imaginação dos visitantes, em si mesma, é relevante para a experiência museológica? Deveria ser. É.

\section{INDEX}

Keywords: imaginary museums, imagination, experience, metaphor

Palavras-chave: museus imaginários, imaginação, experiência, metáfora 


\section{AUTHOR}

RACHEL MORRIS

Director of the London-based company Metaphor (www.metaphor.eu). She is also creator and editor of the online museum, The Museum of Marco Polo (www.momarcopolo.com),

rmorris@metaphor.eu 